Section Editor

John J. Millichap, MD

Teaching Video NeuroImages:

\title{
Trigeminal neuralgia due to compression by the superior cerebellar artery
}

回

Joshua Bakhsheshian, MD, MS

Khodayar Goshtasbi, BS Ben A. Strickland, MD Martin H. Pham, MD

Correspondence to Dr. Bakhsheshian: Joshuabakh@gmail.com

Supplemental data at Neurology.org

Download teaching slides: Neurology.org

\section{Figure Trigeminal neuralgia imaging and microvascular decompression}
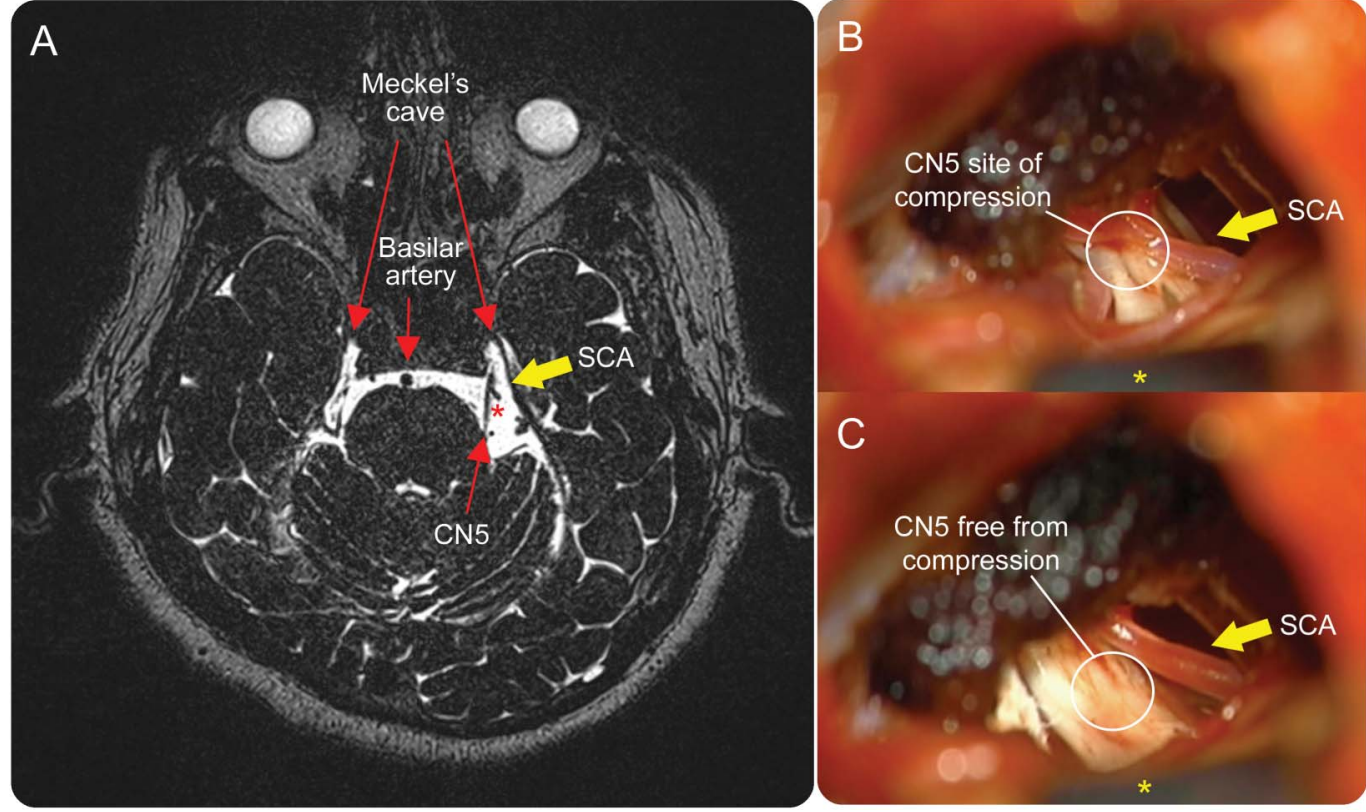

(A) MRI fast imaging employing steady-state acquisition demonstrates left trigeminal nerve compression (region marked by red asterisk) by the left superior cerebellar artery (SCA) (yellow arrow). (B) Left retrosigmoid craniotomy (yellow asterisk marks the retractor on the cerebellum) with microsurgical dissection revealed the trigeminal nerve adherent (likely site of compression) to the left SCA (yellow arrow). (C) The nerve was freed from the pulsating artery (yellow arrow; yellow asterisk marks the retractor on the cerebellum).

A man in his 50 s had longstanding left-sided trigeminal neuralgia triggered by eating and brushing his teeth, which was refractory to maximal medical management. MRI fast imaging employing steady-state acquisition demonstrated left trigeminal nerve compression by the left superior cerebellar artery (figure). Therefore, the patient underwent a craniotomy for microvascular decompression (MVD). In select patients, MVD can be an effective treatment for trigeminal neuralgia. ${ }^{1,2}$ Prognostic indicators of long-term relief include male sex, immediate postoperative relief, and duration of symptoms for less than 8 years. ${ }^{1}$ The patient's adhered nerve was freed from the artery (video at Neurology.org). Facial pain improved substantially in the immediate postoperative period.

\section{AUTHOR CONTRIBUTIONS}

Joshua Bakhsheshian: drafting/revising the manuscript for content, including medical writing for content, study concept or design, analysis or interpretation of data, accepts responsibility for conduct of research and final approval. Khodayar Goshtasbi, Ben Strickland, Martin Pham: acquisition of data, analysis or interpretation of data, accept responsibility for conduct of research and final approval.

\section{STUDY FUNDING}

No targeted funding reported.

\section{DISCLOSURE}

The authors report no disclosures relevant to the manuscript. Go to Neurology.org for full disclosures.

\section{REFERENCES}

1. Barker FG, Jannetta PJ, Bissonette DJ, Larkins MV, Jho HD. The long-term outcome of microvascular decompression for trigeminal neuralgia. N Engl J Med 1996;334: 1077-1084

2. Sindou M. Microvascular decompression for trigeminal neuralgia. In: Practical Handbook of Neurosurgery. Berlin: Springer; 2009:1448-1462. 


\section{Neurology}

\section{Teaching Video NeuroImages: Trigeminal neuralgia due to compression by the superior cerebellar artery \\ Joshua Bakhsheshian, Khodayar Goshtasbi, Ben A. Strickland, et al. \\ Neurology 2017;89; 290 \\ DOI 10.1212/WNL.0000000000004746}

\section{This information is current as of December 11, 2017}

\section{Updated Information \& Services \\ Supplementary Material}

\section{References}

Subspecialty Collections

Permissions \& Licensing

Reprints including high resolution figures, can be found at: http://n.neurology.org/content/89/24/e290.full

Supplementary material can be found at: http://n.neurology.org/content/suppl/2017/12/11/WNL.0000000000004 746.DC1

http://n.neurology.org/content/suppl/2017/12/11/WNL.0000000000004 746.DC2

This article cites 1 articles, 0 of which you can access for free at: http://n.neurology.org/content/89/24/e290.full\#ref-list-1

This article, along with others on similar topics, appears in the following collection(s):

All Education

http://n.neurology.org/cgi/collection/all_education

All Pain

http://n.neurology.org/cgi/collection/all_pain

MRI

http://n.neurology.org/cgi/collection/mri

Trigeminal neuralgia

http://n.neurology.org/cgi/collection/trigeminal_neuralgia

Information about reproducing this article in parts (figures,tables) or in its entirety can be found online at:

http://www.neurology.org/about/about_the_journal\#permissions

Information about ordering reprints can be found online:

http://n.neurology.org/subscribers/advertise

Neurology ${ }^{\circledR}$ is the official journal of the American Academy of Neurology. Published continuously since 1951, it is now a weekly with 48 issues per year. Copyright (O 2017 American Academy of Neurology. All rights reserved. Print ISSN: 0028-3878. Online ISSN: 1526-632X.

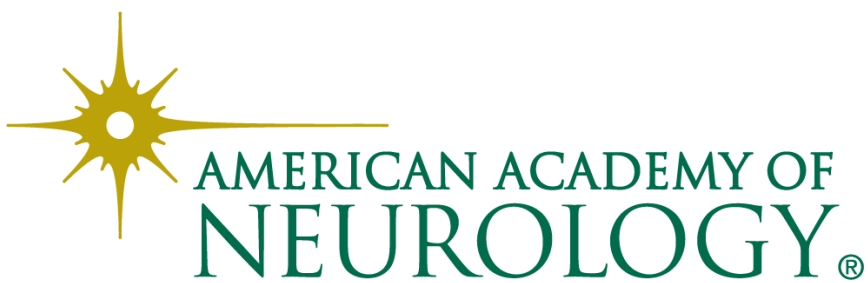

